\title{
INFLUENCE OF DIFFERENT PRODUCTION PROCESSES ON THE BIODEGRADABILITY OF AN FeMn17 ALLOY
}

\author{
VPLIV RAZLIČNIH PROCESOV IZDELAVE NA \\ BIORAZGRADLJIVOST ZLITINE FeMn17
}

\author{
Aleksandra Kocijan, Irena Paulin, Črtomir Donik, Matej Hočevar, Klemen Zelič, \\ Matjaž Godec \\ Institute of Metals and Technology, Lepi pot 11, 1000 Ljubljana, Slovenia \\ aleksandra.kocijan@imt.si \\ Prejem rokopisa - received: 2016-03-31; sprejem za objavo - accepted for publication: 2016-04-06
}

doi:10.17222/mit.2016.055

\begin{abstract}
The purpose of this research was to evaluate the biodegradability of a cast FeMn17 alloy that was processed by hot rolling and annealing, which influenced both the mechanical and corrosion properties of the FeMn17 alloy. The corrosion behaviour and in-vitro biodegradability were investigated by light microscopy, scanning electron microscopy, X-ray diffraction and immersion tests in Hank's solution. Compared to pure Fe, the cast FeMn17 alloy has a better biodegradability (higher corrosion rate). We showed that hot rolling additionally improves the biodegradability, while the annealing process lowers the biodegradability of the FeMn17 alloy.
\end{abstract}

Keywords: biodegradability, FeMn alloy, corrosion, XRD, SEM

Namen raziskave je bil oceniti biorazgradljivost zlitine FeMn17 s predelavo z vročim valjanjem in žarjenjem. Vroče valjanje in žarjenje vplivata na mehanske in korozijske lastnosti zlitine FeMn17. Korozijske lastnosti in biorazgradljivost smo preverjali s svetlobno mikroskopijo, vrstično elektronsko mikroskopijo, rentgensko difrakcijo in s testi potapljanja v Hankovo raztopino. V primerjavi s čistim Fe, ima zlitina FeMn17 veliko boljšo biorazgradljivost (večjo korozijsko hitrost). Pokazali smo, da vroče valjanje dodatno izboljša biorazgradljivost, z žarjenjem pa se biorazgradljivost zlitine FeMn17 poslabša.

Ključne besede: biorazgradljivost, FeMn zlitina, korozija, XRD, SEM

\section{INTRODUCTION}

Biodegradable metallic materials represent a novel class of bioactive biomaterials that can temporarily support tissue healing and should progressively degrade completely without a negative effect on the healing process. $^{1-3}$ Potential applications of these biomaterials are paediatric, orthopaedic (fixation screws and pins) and cardiovascular implants (coronary stents). ${ }^{1,4}$ Biodegradable polymers were first investigated as bioactive biomaterials; however, in recent years biodegradable metallic materials, especially $\mathrm{Fe}$ and $\mathrm{Mg}$ alloys, have received more attention due to their superior mechanical properties and their cytocompatibility. ${ }^{1-3,5}$ Compared with Mg-based materials, Fe-based materials possess similar mechanical properties to stainless steel and are more attractive for applications that require high strength and ductility. ${ }^{1}$ Despite the immense potential of $\mathrm{Fe}$ and $\mathrm{Mg}$ alloys, experiments and clinical trials also exposed their weaknesses: too rapid degradation rates, poor mechanical properties and significant hydrogen evolution during the corrosion process of Mg-based alloys and a too slow degradation of Fe-based alloys. ${ }^{5-8}$

Fe-based alloys may also present problems with certain imaging devices (magnetic resonance imaging, for example) due to the Fe's ferromagnetic nature. However, alloying and heat treatment can modify the mechanical, corrosion, and ferromagnetic properties of pure Fe..$^{1,2}$ The choice and the amount of alloying element is important with respect to the toxicity and degradation behaviour of the $\mathrm{Fe}$ alloy. ${ }^{2} \mathrm{Mn}$ represents a suitable alloying element based on microstructural, magnetic, corrosion, and toxicological considerations. ${ }^{2} \mathrm{Mn}$ (austenite-forming element) transforms $\mathrm{Fe}$ into a nonmagnetic material, lowers the standard electrode potential of $\mathrm{Fe}$ and thus enhances the degradation of the material, which represents an essential trace element necessary in many enzymatic reactions. Newly developed Fe-Mn-based alloys containing up to $35 \%$ of mass fractions of Mn have comparable mechanical properties to stainless steel, faster degradation and improved MRI compatibility. ${ }^{1,2}$ Despite this, the low corrosion rate still represents the major problem fornewly developed Fe-Mn-based alloys.

Non-conventional processing techniques such as powder metallurgy, electrodeposition and inkjet 3Dprinting can achieve the faster degradation of $\mathrm{Fe}-\mathrm{Mn}$ alloys. ${ }^{1,2}$ However, these techniques are rather complex and expensive, therefore it is necessary to further investigate conventional methods, such as casting with additional steel-processing techniques in order to find an economically favourable solution. Research has rarely been made on the influence of subsequent processing and heat treatment on the properties of any conventional, cast, 
Table 1: Chemical composition in mass fractions, $w / \%$

Tabela 1: Kemijska sestava v masnih deležih, w/\%

\begin{tabular}{|c|c|c|c|c|c|c|c|c|}
\hline Material & Mo & $\mathrm{Ni}$ & $\mathrm{Mn}$ & $\mathrm{Cu}$ & $\mathrm{Ti}$ & $\mathrm{Si}$ & $\mathrm{C}$ & $\mathrm{Fe}$ \\
\hline Pure Fe & <LOD & 0.14 & 0.262 & 0.043 & $<$ LO & 0.051 & 0.19 & balance \\
\hline FeMn17 alloy & 0.021 & 0.182 & 17.08 & 0.446 & 0.058 & 0.167 & 0.08 & balance \\
\hline
\end{tabular}

biodegradable, metallic materials, including Fe-Mnbased alloys. The aim of the present study was to investigate the influence of three basic steel-processing methods (casting, hot rolling and annealing) on the corrosion behaviour of the biodegradable Fe-Mn-based alloy due to the formation of less-corrosion-resistant deformational martensite. ${ }^{9}$

\section{EXPERIMENTAL PART}

Material preparation - The investigated Fe-based alloy with $17 \%$ of mass fractions of Mn (FeMn17) was produced from relatively pure Fe and $\mathrm{Mn}$. Both materials were melted in an induction furnace under air atmosphere at approximately $1700{ }^{\circ} \mathrm{C}$ and cast into two iron moulds. One mould was left to cool down in air atmosphere and the other one was after casting in mould, hot rolled at approximately $1000{ }^{\circ} \mathrm{C}$ for a $33 \%$ reduction. Parts of both samples were annealed at $1050{ }^{\circ} \mathrm{C}$ for $1 \mathrm{~h}$ and then furnace cooled. The materials were analysed and the results were compared with pure Fe. The chemical compositions of the alloy and the pure Fe were determined using an X-ray fluorescence spectrometer XRF (Thermo Scientific Niton XL3t GOLDD+) and arepresented in Table $\mathbf{1 .}$

Metallographic investigation - Samples were cut with a water-cooled saw and cross-sections of the samples were prepared by the standard metallographic techniques of grinding and polishing. The samples were etched with $3 \% \mathrm{Nital}$, an ethanol solution of $\mathrm{HCl}_{(\mathrm{aq})}$ and an ethanol solution of $\mathrm{HNO}_{3(\mathrm{aq})}$. The characterization of the material was performed using a light microscope (LM, Microphot FXA Nikon with Olympus DP73) and a scanning electron microscope coupled with an energy-dispersive spectrometer (SEM, JEOL JSM-6500F, EDS INCA ENERGY 400) for analyses of the inclusions and phases.

$X$-ray Powder Diffraction - The samples were measured using a Panalyitical XPERT Pro PW 3040/60 goniometer $2 \theta$ between $15-90^{\circ}$ with a step size of $0.002^{\circ}$ and a scan step time of $100 \mathrm{~s}$ on each step. $\mathrm{Cu}$ with $\left(K_{\alpha}=\right.$ $0.154 \mathrm{~nm}$ ) anode was used with a current of $40 \mathrm{~mA}$ and a potential of $45 \mathrm{kV}$.

Mechanical properties - The microhardness was measured by Vickers HV5 (5 kg load, 11s -Instron Tukon 2100B).

Electrochemical measurements - Were performed on prepared specimens, ground with $\mathrm{SiC}$ emery paper down to 1200 grit. The experiments were carried out in a simulated physiological Hank's solution, containing $8 \mathrm{~g} / \mathrm{L}$ $\mathrm{NaCl}, \quad 0.40 \mathrm{~g} / \mathrm{L} \quad \mathrm{KCl}, 0.35 \mathrm{~g} / \mathrm{L} \quad \mathrm{NaHCO}_{3}, 0.25 \mathrm{~g} / \mathrm{L}$
$\mathrm{NaH}_{2} \mathrm{PO}_{4} \times 2 \mathrm{H}_{2} \mathrm{O}, 0.06 \mathrm{~g} / \mathrm{L} \mathrm{Na}_{2} \mathrm{HPO}_{4} \times 2 \mathrm{H}_{2} \mathrm{O}, 0.19 \mathrm{~g} / \mathrm{L}$ $\mathrm{CaCl}_{2} \times 2 \mathrm{H}_{2} \mathrm{O}, \quad 0.41 \quad \mathrm{~g} / \mathrm{L} \quad \mathrm{MgCl}_{2} \times 6 \mathrm{H}_{2} \mathrm{O}, \quad 0.06 \mathrm{~g} / \mathrm{L}$ $\mathrm{MgSO}_{4} \times 7 \mathrm{H}_{2} \mathrm{O}$ and $1 \mathrm{~g} / \mathrm{L}$ glucose, at $\mathrm{pH}=7.8$. All chemicals were from Merck, Darmstadt, Germany. The measurements were performed using a three-electrode, flat BioLogic corrosion cell (volume $0.25 \mathrm{~L}$ ). The test specimen was employed as the working electrode (WE). The reference electrode (RE) was a saturated calomel electrode (SCE, $0.242 \mathrm{~V}$ vs. SHE) and the counter electrode (CE) was a platinum net. Electrochemical measurements were recorded by using a BioLogic Modular Research Grade Potentiostat/Galvanostat/FRA Model SP-300 with an EC-Lab®software V10.44. The specimens were immersed in the solution $1 \mathrm{~h}$ prior to the measurement in order to stabilize the surface at the open-circuit potential (OCP). The potentiodynamic curves were recorded after $1 \mathrm{~h}$ of sample stabilisation at the open-circuit potential (OCP), starting the measurement at $250 \mathrm{mV}$ vs. SCE more negative than the OCP. The potential was then increased, using a scan rate of $1 \mathrm{mV} \mathrm{s}^{-1}$, until the transpassive region was reached. The linear polarisation measurements were performed at $\pm 25 \mathrm{mV}$ according to the OCP, using a scan rate of $0.01 \mathrm{mV} \mathrm{s}^{-1}$.

\section{RESULTS AND DISSCUSION}

\subsection{Microstructure characterization}

The microstructures of all four samples, i.e., cast, hot rolled and both samples after annealing at $1050{ }^{\circ} \mathrm{C}$ and furnace cooled down, are shown in Figure 1. There is no difference in the chemical composition, where as there are some differences in the microstructure. In the cast sample, the cast structure occurs upon cooling, though the cooling rate is too high for equilibrium phase transformation, as predicted from the $\mathrm{Fe}-\mathrm{Mn}$ phase diagram. We observed some boundary segregations rich in $\mathrm{Mn}$ and inclusions of $\mathrm{MnS}$ and $\mathrm{TiN}$, which were also confirmed by the EDS analyses. The observed average grain size for these samples was approximately $350 \mu \mathrm{m}$. There was also some smaller porosity present in the microstructure. The cast + annealed sample (Figure 1b) has a similar microstructure with the same precipitations and inclusions that are ubiquitous at grain boundary and in the grains. The difference is in the much larger grain sizes (average of approx. $1200 \mu \mathrm{m}$ ) and more segregation of $\mathrm{Mn}$ at the grain boundaries according to the prolongation of the time available for the cooling after annealing.

In the hot-rolled sample was observed, beside austenite, also traces of strain-induced martensite and deformation twins. Due partly to the recrystallization, the microstructure consists of large and small grains. The 
A. KOCIJAN et al.: INFLUENCE OF DIFFERENT PRODUCTION PROCESSES ON THE BIODEGRADABILITY ...

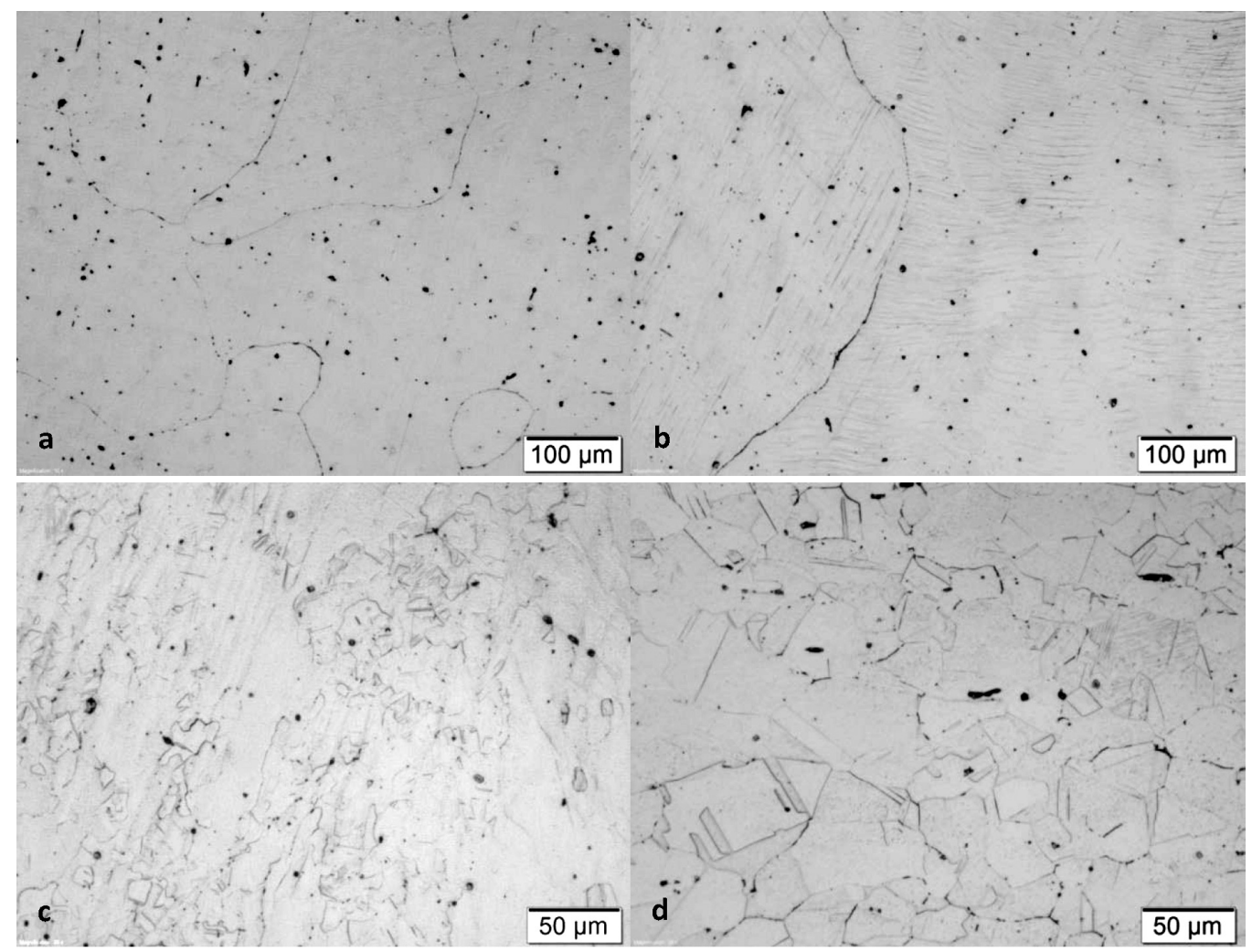

Figure 1: LM images of microstructure: a) cast sample, b) cast + annealed sample, at $1050{ }^{\circ} \mathrm{C}$ c) hot-rolled sample, and d) hot-rolled + annealed sample

Slika 1: LM-posnetki mikrostruktur: a) ulit vzorec, b) ulit + žarjen na $1050{ }^{\circ} \mathrm{C}$, c) vroče valjan vzorec in d) vroče valjan + žarjen vzorec

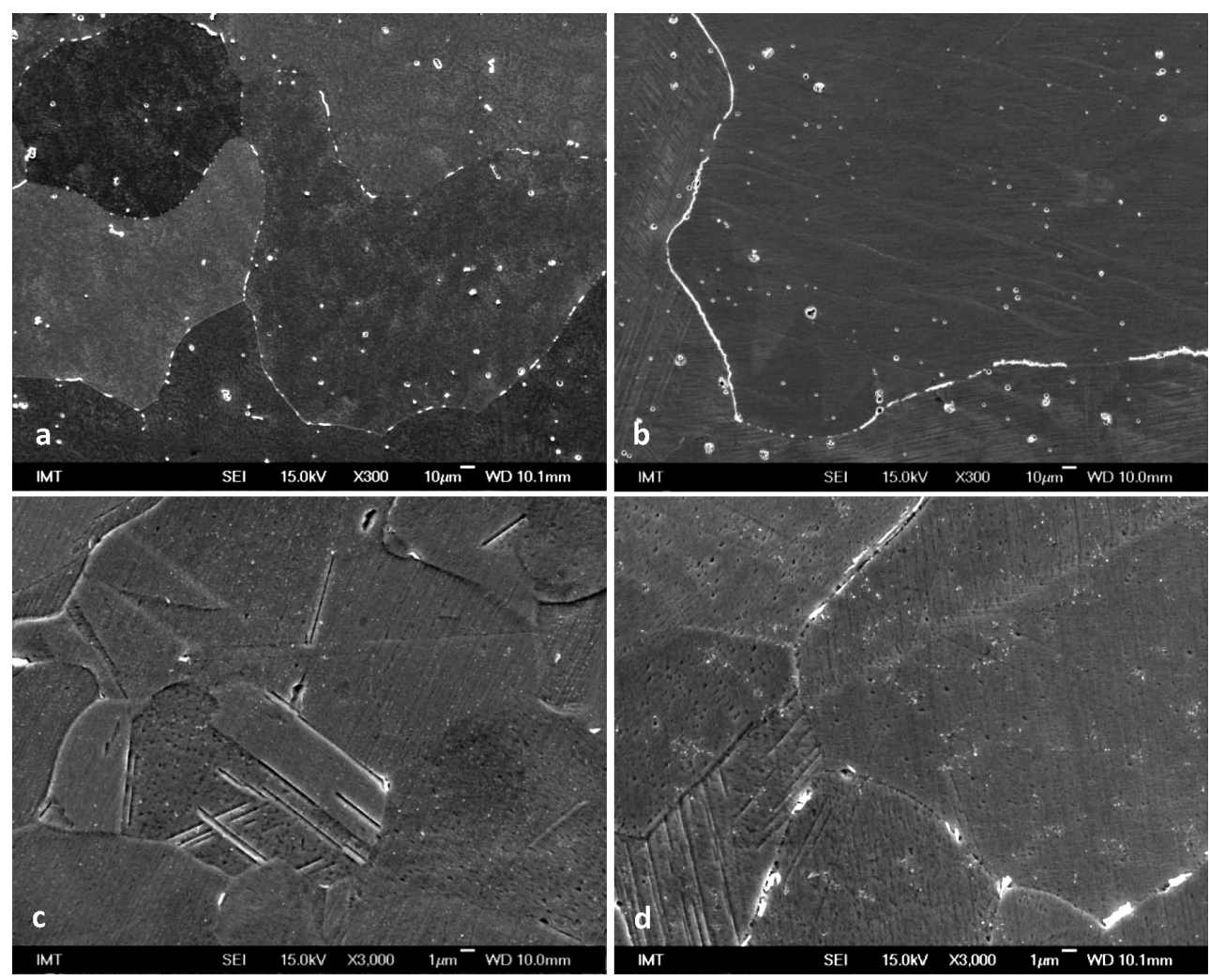

Figure 2: SEM images of microstructure: a) cast sample, b) cast + annealed sample, at $1050{ }^{\circ} \mathrm{C}$, furnace cooled down, c) hot-rolled sample and d) hot-rolled + annealed at $1050{ }^{\circ} \mathrm{C}$

Slika 2: SEM-posnetki mikrostruktur: a) ulit vzorec, b) ulit + žarjen na $1050^{\circ} \mathrm{C}$, c) vroče valjan vzorec in d) vroče valjan + žarjen vzorec 


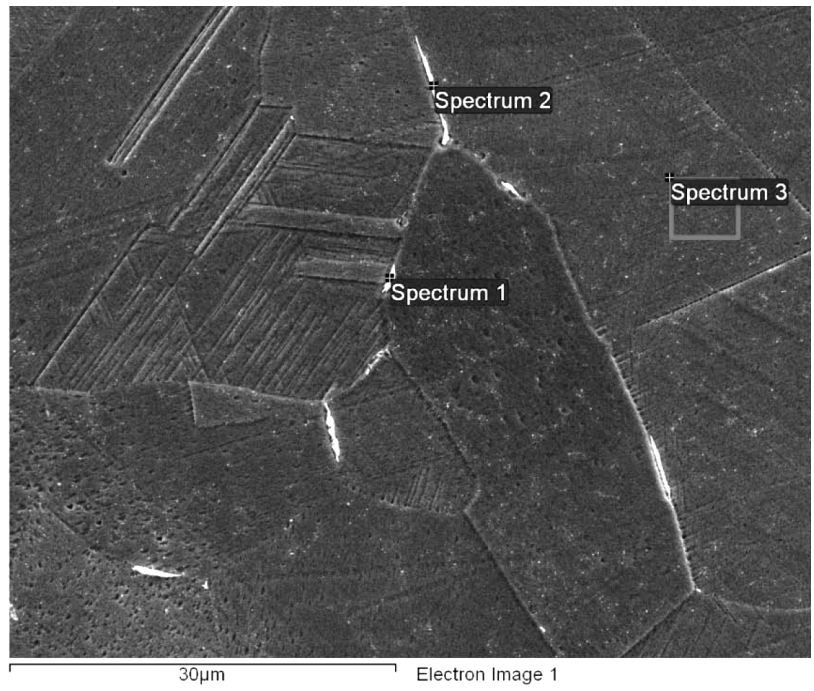

Figure 3: SEM image of microstructure and areas of EDS measurements on the hot-rolled sample

Slika 3: SEM-posnetek mikrostrukture z mesti EDS-analiz vroče valjanega vzorca

increased concentration of Mn was observed on the grain boundaries well as the $\mathrm{MnS}$ and TiN inclusions in the matrix as determined by the EDS analyses.

After annealing the sample has a recrystallized microstructure with smaller grains, an average of approximately $40 \mu \mathrm{m}$ and the strain-induced martensite is still present in the microstructure. This means the annealing temperature was too low or the annealing time was too short for complete recrystallization. The SEM imaging was performed at higher magnification for details of the microstructures (Figure 2). In the microstructures of the hot rolled and the hotrolled + annealed FeMn17 samples the similar mixture of martensitic and austenitic microstructure was observed, similar to those previously described by Y. K. Lee at al. ${ }^{10}$, J. Martinez at al. ${ }^{11}$ and M. Schinhammer at al. ${ }^{12}$ However, there was no

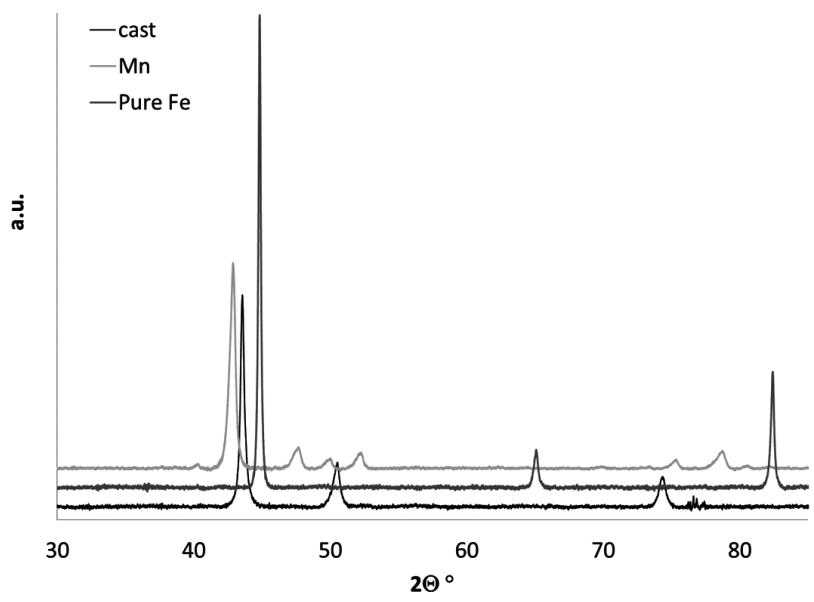

Figure 4: The XRD patterns for specimens - the two original materials,pure Fe and $\mathrm{Mn}$, and the specimen of cast FeMn17 alloy Slika 4: XRD-spektri dveh osnovnih materialov, čistega Fe in Mn, ter ulite zlitine FeMn17 literature presenting only cast FeMn17 material. The EDS analyses were performed for a determination of the precipitations and inclusions in the microstructure (Figure 3).

\subsection{Microhardness}

Microhardness by Vickers (HV) was measured with a $5-\mathrm{kg}$ load for $11 \mathrm{~s}$. The results are in Table 2. The pure Fe has, as expected, the lowest microhardness. The higher microhardness is achieved in the hot-rolled samples, whereas the HV decreases with the annealing of the samples. In cast sample, the HV is not different according to the sample cast + annealed and cooled down with the furnace. On the other hand, all the HVs are lower thanthe one of the hot-rolled samples.

Table 2: Microhardness HV 5

Tabela 2: Mikrotrdota po HV5

\begin{tabular}{|c|c|c|c|c|c|}
\hline Samples & Pure Fe & Cast & $\begin{array}{c}\text { Hot } \\
\text { rolled }\end{array}$ & $\begin{array}{c}\text { Cast }+ \\
\text { annealed }\end{array}$ & $\begin{array}{c}\text { Hot rolled }+ \\
\text { annealed }\end{array}$ \\
\hline HV 5 & 110 & 181 & 240 & 180 & 210 \\
\hline
\end{tabular}

\subsection{X-ray powder diffraction}

Diffraction peaks of the FeMn17 specimens correspond to the phases previously observed in FeMn17. These phases are similar to those observed by Y. K. Lee et al. ${ }^{10}$, J. Martinez et al. ${ }^{11}$ and H. Hermawan et al. ${ }^{13}$ in various $\mathrm{Fe}-\mathrm{Mn}$ binary alloys at room temperature. Figure 4 shows observed peaks for the FeMn17 alloy and two starting materials, pure $\mathrm{Fe}$ and $\mathrm{Mn}$. The highest peak at $2 \theta=43.6^{\circ}$ corresponds to $(111)$, the next peak at $50.5^{\circ}$ to (002) and the last peak, at $74.4^{\circ}$, corresponds to (022). The results correspond to a cubic crystal system, with the space group $\mathrm{F} \mathrm{m}-3 \mathrm{~m}$ and space group number 225 , the cubic cell unit is face centred (fcc). The XRD spectrum shows peaks at different $2 \theta$ for pure $\mathrm{Fe}$ and $\mathrm{Mn}$, which proves that all the starting materials were melted in a new alloy with a different cell unit and different chemical composition and mechanical properties was prepared.

The highest intensity peak forthe pure Fe, as a starting material, is observed at $44.8^{\circ}$ and corresponds to (011), the next peak is observed at $82.4^{\circ}$ corresponding to (112) and the peak with lowest intensity was at $65.1^{\circ}$, which corresponds to (002). This is also a cubic crystal system with a different space group, I $\mathrm{m}-3 \mathrm{~m}$, and the space number is 229 . The cell unit for used pure Fe, as the main alloying material is body centred cubic (bcc).

The other starting material used for the alloying was Mn. The XRD spectrum for the Mn shows main peaks at $43.0^{\circ}$, which corresponds to (330), next peak at $47.8^{\circ}$ corresponds to (332) and two peaks with similar intensities at $52.3^{\circ}$ and $78.9^{\circ}$ that correspond to (510) and (721), respectively. This is also a cubic crystal system with the space group I $-43 \mathrm{~m}$ and the corresponding space group number 217 , the cubic cell unit is body centred cubic (bcc). 


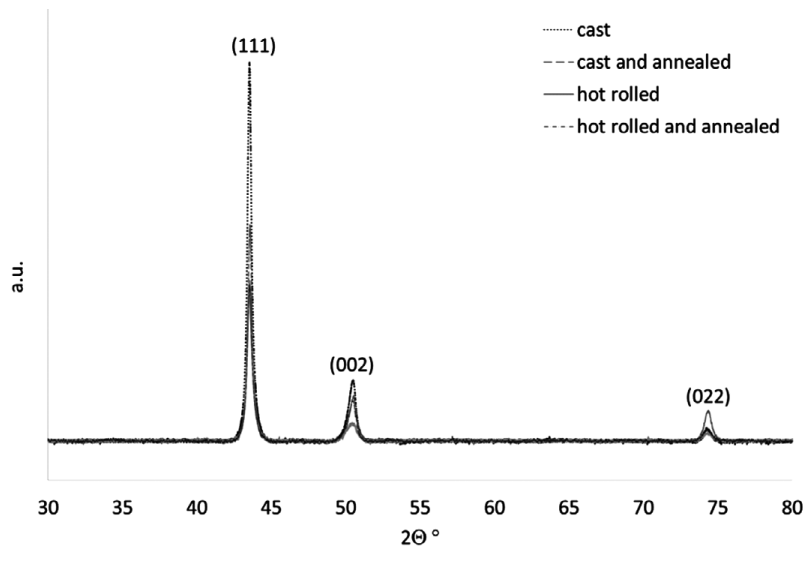

Figure 5: XRD patterns for specimens of differently produced FeMn17 alloy

Slika 5: XRD-spekter različno obdelane zlitine FeMn17

From the observed results it can be concluded that the alloy consists of just one phase, FeMn and some non-metallic inclusions. Any other potential phases in the alloy are below $2 \%$, which is also the limit of detection of the XRD technique. This corroborates SEM/EDS and LM results where onlysome additional non-metallic inclusions and Mn-rich grain-boundaries are present in the matrix of the investigated FeMn17 alloy.

Figure 5 shows the comparison of XRD spectra between differently processed FeMn17 alloys. The only difference between the spectra is in the intensities of the peaks and not in the peak positions, which corroborates the fact that the only difference between these specimens was just the thermal and mechanical treatments. The most intense peak was for the first peak at $43.6^{\circ}$ of FeMn17 that was cast in a metal mould, and hot rolled, while the preferential orientation was observed due to the hot rolling, which explains the decrease of the intensity of the peak at $74.4^{\circ}$ in comparison to the other specimens. The annealing of the specimens reduces the preferential orientation so that the intensities in the XRD spectrum are shifted to lower values and become very similar to the samples just cast in a metal mould.

\subsection{Electrochemical measurements}

Figure 6 represents the potentiodynamic behaviour of the investigated materials in a simulated physiological Hank's solution at $\mathrm{pH}=7.8$. The influence of different production parameters on the corrosion behaviour of the tested materials compared to pure Fe was investigated. After $1 \mathrm{~h}$ of stabilization at the OCP, the corrosion potential $\left(E_{\text {corr }}\right)$ for pure Fe in Hank's solution was approximately $-0.67 \mathrm{~V}$ vs. SCE. Hot rolled + annealed FeMn17 as well as cast + annealed FeMn17 alloys exhibited similar potentiodynamic behaviour as pure Fe, with $E_{\text {corr }}$ at approximately $-0.68 \mathrm{~V}$ vs. SCE. In the case of cast + hot-rolled FeMn17 alloys the corrosion stability decreased compared to other three specimens and the Tafel region was shifted to higher corrosion-current densities and $E_{\text {corr }}$ was $-0.74 \mathrm{~V}$ vs. SCE. None of the investigated samples in Hank's solution exhibited typical potentiodynamic behaviour with a passive region followed by a transpassive region.

Figure 7 represents linear polarisation curves for the investigated samples in a simulated physiological Hank's solutionat $\mathrm{pH}=7.8$. The calculations were performed from linear polarization measurements using Equation (1):

$$
R_{\mathrm{p}}=\beta_{\mathrm{a}} \beta_{\mathrm{c}} /\left(2.3 I_{\text {corr }}\left(\beta_{\mathrm{a}}+\beta_{\mathrm{c}}\right)\right)
$$

The polarization resistance, $R_{\mathrm{p}}$, is evaluated from the linear polarization curves by applying a linear leastsquares fit of the data around $\pm 10 \mathrm{mV} E_{\text {corr. }}$ The corrosion current, $I_{\text {corr }}$, is calculated from $R_{p}$, the least-squares slope, and the Tafel constants, $\beta_{\mathrm{a}}$ and $\beta_{c}$, of $120 \mathrm{mV}$ decade $^{-1}$. The value of $E_{(I=0)}$ is calculated from the least-squares intercept. The corrosion rate was calculated by using the following conversion equation (2):

$$
v_{\text {corr }}=C(E W / d)\left(I_{\text {corr }} / A\right)
$$

where $E W$ is the equivalent weight of the sample in $g, A$ is the sample area in $\mathrm{cm}^{2}, d$ is its density in $\mathrm{g} / \mathrm{mL}$, and $C$ is a conversion constant, which is dependent upon the desired units. The results demonstrated steeper linear polarisation curves and therefore a lower corrosion resistance of cast + hot-rolled FeMn17 alloys compared to pure Fe, cast + annealed FeMn17 and hot rolled + annealed FeMn17 alloys. The corrosion parameters calculated from the linear polarisation and potentiodynamic measurements in a simulated physiological Hank's solution indicated that the corrosion stability of the cast + hot rolled FeMn17 alloys was lower compared to pure $\mathrm{Fe}$, cast + annealed and hot rolled + annealed FeMn17 alloys. This was proven by the higher corrosion currents $\left(I_{\text {corr }}\right)$, the higher corrosion rates $\left(v_{\text {corr }}\right)$ and the lower polarization resistances $\left(R_{\mathrm{p}}\right)$, compared to pure Fe, cast + annealed and hot rolled + annealed FeMn17 alloys (Table 3).

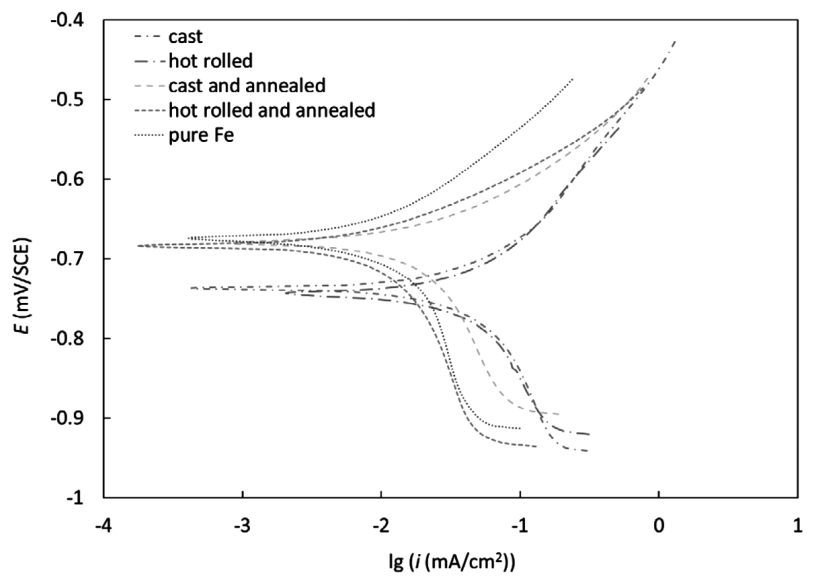

Figure 6: Potentiodynamic curves for pure Fe, cast, hot rolled, cast + annealed and hot rolled + annealed FeMn17 alloy in a simulated physiological Hank's solution

Slika 6: Potenciodinamske krivulje za čisto Fe, ulito in vroče valjano, ulito + žarjeno in vroče valjano + žarjeno FeMn17 zlitino 


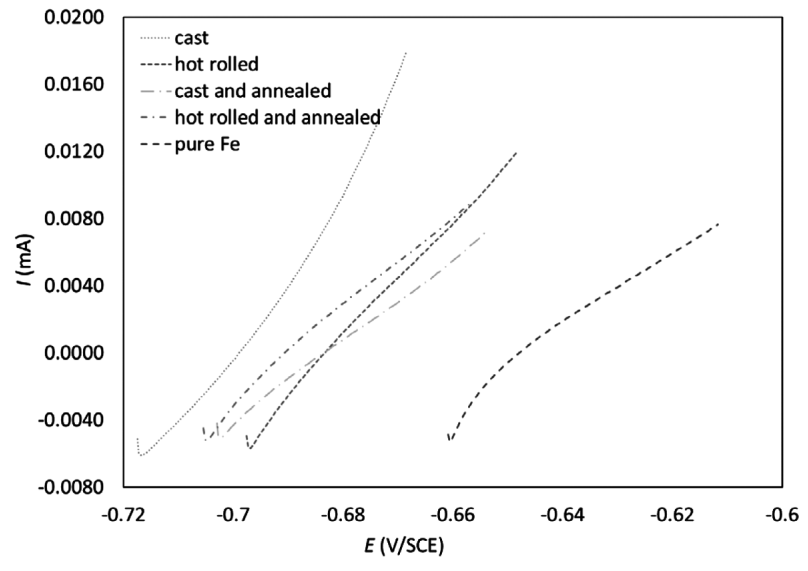

Figure 7: Linear polarisation curves for pure Fe, cast, hot rolled, cast + annealed and hot rolled + annealed FeMn17 alloy in a simulated physiological Hank's solution.

Slika7: Linearne polarizacijske krivulje za čisto Fe, ulito in vroče valjano, ulito + žarjeno in vročevaljano + žarjeno zlitino FeMn17

A wide variety of biodegradability/corrosion studies have been made using the electrochemical testing of the desired designed materials due to aconvenient and easy method to evaluate the corrosion property by testing theOCP (open-circuit potential), polarization curves and EIS(electrochemical impedance spectroscopy) via a three-electrode system. ${ }^{6-8,12,13,15-17}$ Very similar results of corrosion testing with potentiodynamic testing were observed by $\mathrm{H}$. Hermawan ${ }^{13}$ with one distinctive difference, our pure Fe behaved biodegradability much more similar to the FeMn17 alloy than theirs.

In the present biodegradable material design study, the three design criteria as listed by H. Hermawan ${ }^{1}$ have been considering fordeveloping a new alloy for biodegradability: a) mechanical properties that approach to those of AISI $316 \mathrm{~L}$; b) degradation rate that matches with the remodelling period (6-12 months) A. Schomig et al. ${ }^{14}$ and complete disappearance of the implant material within a reasonable period (corrosion rate in the range of $0.1 \mathrm{~mm} /$ year); and c) no toxic substances are released during the degradation process (just pure Fe and Mn with minor non-metallic inclusions).

Table 3: Corrosion parameters calculated from the electrochemical measurements

Tabela 3: Korozijski parametri izračunani iz elektrokemijskih meritev

\begin{tabular}{|c|c|c|c|c|}
\hline Material & $\begin{array}{c}E_{(I=0)} \\
(\mathrm{mV})\end{array}$ & $\begin{array}{c}I_{\text {corr }} \\
(\mu \mathrm{A})\end{array}$ & $\begin{array}{c}R_{\mathrm{p}} \\
(\mathrm{k} \Omega)\end{array}$ & $\begin{array}{c}v_{\text {corr }} \\
(\mathrm{nm} / \text { year })\end{array}$ \\
\hline Pure Fe & -675 & 8.7 & 4.8 & 102 \\
\hline Cast & -737 & 40.6 & 2.4 & 486 \\
\hline Cast + hot rolled & -742 & 44.7 & 2.1 & 537 \\
\hline Cast + annealed & -676 & 18.0 & 3.7 & 216 \\
\hline $\begin{array}{c}\text { Cast + hot rolled + } \\
\text { annealed }\end{array}$ & -682 & 14.3 & 4.3 & 172 \\
\hline
\end{tabular}

In the present study, we focused on a comparison of the biodegradability of a produced FeMn17 alloy after different preparation processing, i.e., casting, hot rolling and annealing. All the prepared specimens were compared to pure Fe.

With additions of $\mathrm{Mn}$ the mechanical properties increase and the corrosion resistance decreases. The process parameters influenced the biodegradability as well as the mechanical properties. The produced material, cast and hot rolled, has interior stress and that increases the biodegradability, though the annealing process increases the stability of the material and the corrosion resistance. The microstructure differences of the material are notable in the grain growth of the annealed sample and the recrystallization in the annealed hot-rolled sample.

The electrochemical investigation confirmed the enhanced biodegradability of the developed FeMn17 alloy compared to pure Fe. We confirmed that cast as well as additionally hot-rolled specimens exhibited a pronounced corrosion instability compared to the annealed material.

\section{Acknowledgement}

This work was carried out within the framework of the Slovene programme P2-0132, "Fizika in kemija površin kovinskih materialov" of the Slovenian Research Agency, whose support is gratefully acknowledged by the authors.

\section{REFERENCES}

${ }^{1}$ H. Hermawan, Biodegradable Metals, From Concept to Applications, 1st ed., Springer, Berlin 2012, 69, doi:10.1007/978-3-642-31170-3

${ }^{2}$ Y. F. Zheng, X. N. Gu, F. Witte, Biodegradable metals, Materials Science and Engineering: R, Reports, 77 (2014) 1-34, doi:10.1016/ j.mser.2014.01.001

${ }^{3}$ H. Hermawan, D. Dubé, D. Mantovani, Developments in metallic biodegradable stents, Acta Biomaterialia, 6 (2010) 5, 1693-1697, doi:10.1016/j.actbio.2009.10.006

${ }^{4}$ H. Hermawan, D. Mantovani, Degradable metallic biomaterials: the concept, current developments and future directions, Minerva Biotecnologica, 21 (2009) 4, 207-216

${ }^{5}$ M. P. Staiger, A. M. Pietak, J. Huadmai, G. Dias, Magnesium and its alloys as orthopedic biomaterials: A review, Biomaterials, 27 (2006) 9, 1728-1734, doi:10.1016/j.biomaterials.2005.10.003

${ }^{6} \mathrm{Z}$. Zhen, T. Xi, Y. Zheng, A review on in vitro corrosion performance test of biodegradable metallic materials, Transactions of Nonferrous Metals Society of China, 23 (2013) 8, 2283-2293, doi:10.1016/ S1003-6326(13)62730-2

${ }^{7}$ B. Liu, Y. F. Zheng, Effects of alloying elements (Mn, Co, Al, W, Sn, $\mathrm{B}, \mathrm{C}$ and $\mathrm{S}$ ) on biodegradability and in vitro biocompatibility of pure iron, Acta Biomaterialia, 7 (2011) 3, 1407-1420, doi:10.1016/ j.actbio.2010.11.001

${ }^{8}$ D. Vojtěch, J. Kubásek, J. Čapek, I. Pospíšilová, Comparative mechanical and corrosion studies on magnesium, zinc and iron alloys as biodegradable metals, Mater. Tehnol., 49 (2015) 6, 877-882, doi:10.17222/mit.2014.129 
${ }^{9}$ L. L. Shreir, R. A. Jarman, G.T. Burstein, Corrosion Volume 1, Metal/Environment Reactions, 3rd ed., Oxford 1994, 3184, doi:10.1016/B978-0-08-052351-4.50001-7

${ }^{10}$ Y. K. Lee, J. H. Jun, C. S. Choi, Damping capacity in Fe-Mn bi- nary alloys, ISIJ International, 37 (1997) 10, 1023-1030, doi:10.2355/ isijinternational.37.1023

${ }^{11}$ J. Martinez, S. M. Cotes, A. F. Cabrera, J. Desimoni, A. Fernández Guillermet, On the relative fraction of $\varepsilon$ martensite in $\gamma$-Fe-Mn alloys, Materials Science and Engineering A, 408 (2005), 26-32, doi:10.1016/j.msea.2005.06.019

${ }^{12}$ M. Schinhammer, A. C. Hänzi, J. F. Löffler, P. J. Uggowitzer, Design strategy for biodegradable Fe-based alloys for medical applications, ActaBiomaterialia, 6 (2010) 5, 1705-1713, doi:10.1016/j.actbio. 2009.07.039

${ }^{13}$ H. Hermawan, D. Dubé, D. Mantovani, Degradable metallic biomaterials, Design and development of Fe-Mn alloys for stents, Journal of Biomedical Materials Research Part A, 93 (2010) 1, 1-11, doi: 10.1002/jbm.a.32224
${ }^{14}$ A. Schömig, A. Kastrati, H. Mudra, R. Blasini, H. Schühlen, V. Klauss, G. Richardt, F. J. Neumann, Four-year experience with Palmaz-Schatz stenting in coronary angioplasty complicated by dissection with threatened or present vessel closure, Circulation 90 (1994) 6, 2716-2724, doi: 10.1161/01.CIR.90.6.2716

${ }^{15}$ M. Schinhammer, P. Steiger, F. Moszner, J. F. Löffler, P. J. Uggowitzer, Degradation performance of biodegradable Fe-Mn-C(-Pd) alloys, Materials Science and Engineering: C, 33 (2013) 4, 1882-1893, doi:10.1016/j.msec.2012.10.013

${ }^{16} \mathrm{~F}$. Moszner, Fe-Mn-Pd maraging steels for biodegradable implant applications, PhD thesis, ETH-Zürich 2014, doi.org/10.3929/ ethz-a-010211762

${ }^{17}$ B. Liu, Y. F. Zheng, L. Ruan, In vitro investigation of Fe30Mn6Si shape memory alloy as potential biodegradable metallic material, Materials Letters, 65 (2011) 3, 540-543, doi:10.1016/j.matlet. 2010.10.068 